\title{
Academic And Practitioner Interests Regarding Emerging Technologies In Accounting
}

Thomas J. Tribunella, (E-mail: ttribunella@ cob.rit.edu), Rochester Institute of Technology M. Pamela Neely, (E-mail: pneely@ cob.rit.edu), Rochester Institute of Technology

Heidi R. Tribunella, (E-mail: tribunella@simon.rochester.edu), University of Rochester

\begin{abstract}
In this paper we investigate the differences between practitioner and academic interests in emerging technologies. We compare and contrast the results of an accounting faculty survey to the AICPA's (American Institute of Certified Public Accountants) Top Technology list. It appears that academics and practitioners have significantly different interests concerning emerging technologies. Furthermore, technology interests for both groups change over time. We then discuss the problems that arise from the differing points of view and suggest some possible solutions.
\end{abstract}

\section{INTRODUCTION}

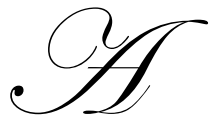

ccounting Information Systems (IS) and IS Auditing courses are standard offerings in most accounting programs. This is a reflection of the growing importance of information systems and emerging technologies in the accounting profession. Emerging technologies (ET) such as electronic commerce, XBRL (extensible business reporting language), database management, paperless office technology, and enterprise systems are pervasive in the current business environment. In the future, it appears that emerging technologies will grow in importance. When the career management firm Robert Half asked: "Other than financial expertise, which one of the following do you think will be most critical to an accounting professional's career success?" 44 percent of CFOs surveyed ranked technology expertise first (Robert Half International, 2004).

Exhibit 1: Robert Half International Survey Results

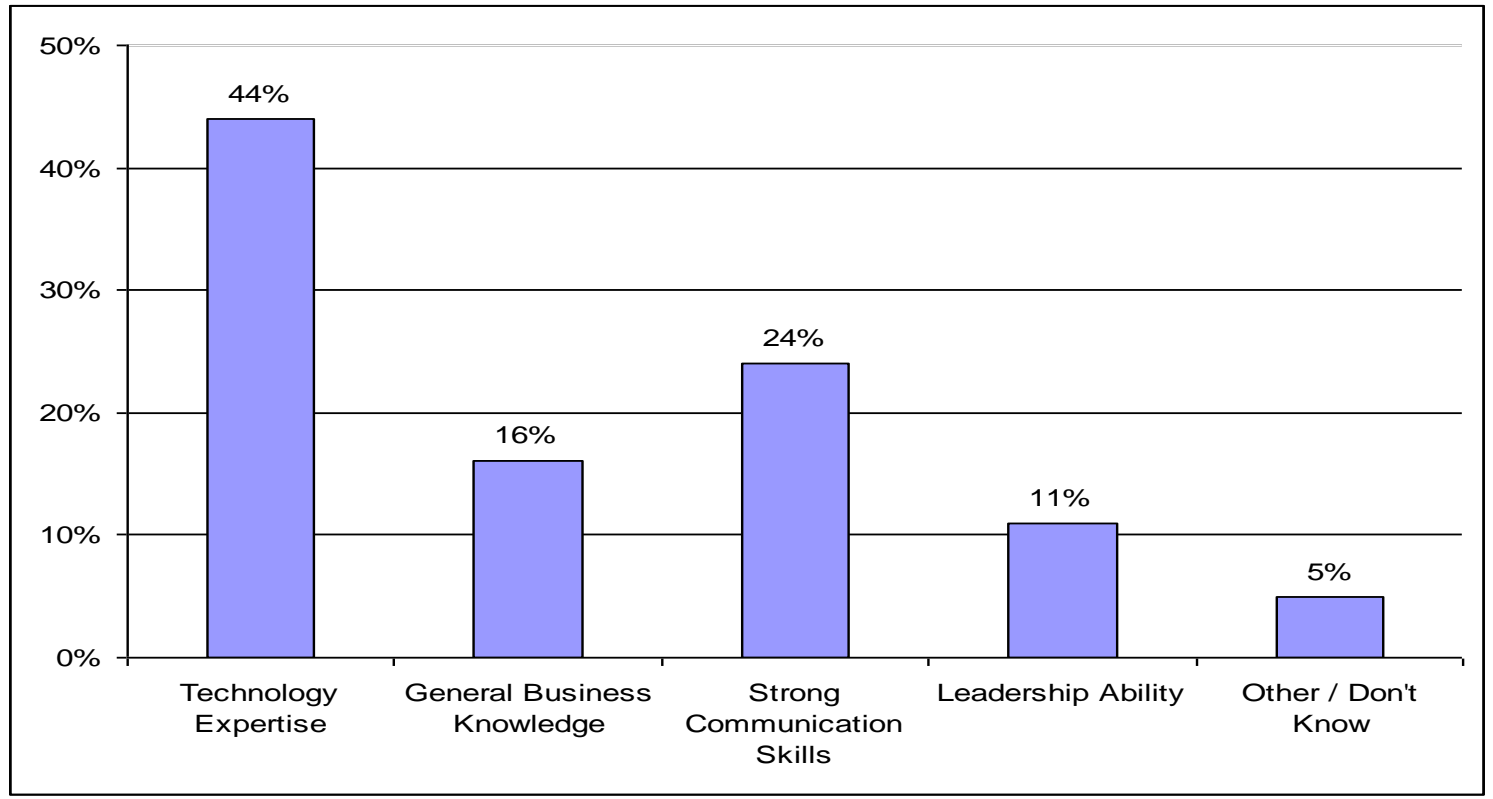


In spite of this recognition, there are significant differences between what accounting professors teach and what practitioners rank as important. This study will examine these differences and how they may affect the future of the accounting profession. We will then suggest some solutions to help bridge the gap between academic and practitioner points of view.

\section{LITERATURE REVIEW AND CONTRIBUTIONS OF THIS STUDY}

\section{Literature Review}

Several journal articles were reviewed to understand previous research conducted in the area of practitioner and faculty interests in technology. A broad range of articles have addressed this issue. The primary types of methodologies used are: faculty surveys, surveys of practitioners, review of text book contents and the examination of course syllabi. Also, specific topics such as XBRL and database technologies have been studied. Calderon, Olsen and Conrand (1996) studied the coverage of database topics in Accounting Information Systems (AIS) courses. They found that the coverage of database tools and techniques used in practice was low. Karim, Deshmukh and Romine (2003) studied the coverage of XBRL in AIS courses. They found that $40 \%$ of AIS professors do not cover XBRL and $60 \%$ of accounting students are completely unfamiliar with XBRL.

Exhibit 2 lists several papers that have examined IS and ET faculty and practitioner interests. From a review of Exhibit 2 we can see that faculty rarely agree with practitioners when ranking important technologies. Furthermore, there is a rapid turnover of the technology interests of both academics and practitioners. However, internal control and database issues seem to be a constant theme.

Exhibit 2: Literature Review of AIS Teaching Interests

\begin{tabular}{|c|c|c|c|c|c|c|}
\hline Authors & Davis \& Leitch & Heagy \& Rakow & Smith \& Bain & $\begin{array}{l}\text { Groomer \& } \\
\text { Murthy }\end{array}$ & $\begin{array}{l}\text { Bain, Blankley \& } \\
\text { Smith }\end{array}$ & $\begin{array}{l}\text { Bain, Blankley \& } \\
\text { Smith }\end{array}$ \\
\hline Year & 1988 & 1991 & 1993 & 1996 & 2002 & 2002 \\
\hline Survey & 809 & 448 & 125 & 453 & 829 & 600 \\
\hline $\begin{array}{l}\text { Usable } \\
\text { Response }\end{array}$ & 132 & 172 & 52 & 165 & 162 & 111 \\
\hline Method & $\begin{array}{c}\text { Survey of Recent } \\
\text { Accounting } \\
\text { Graduates }\end{array}$ & Faculty Survey & Faculty Survey & Faculty Survey & Faculty Survey & $\begin{array}{l}\text { Survey of } \\
\text { Accounting } \\
\text { Graduates }\end{array}$ \\
\hline 1 & Spreadsheets & Internal Controls & Internal Control & Cycles & Internal Control & Internal Control \\
\hline 2 & Software & $\begin{array}{c}\text { Manual } \\
\text { Accounting } \\
\text { Systems } \\
\end{array}$ & Control & $\begin{array}{c}\text { Controls \& } \\
\text { Auditing } \\
\end{array}$ & $\begin{array}{c}\text { Transaction } \\
\text { Processing } \\
\text { Systems \& } \\
\text { Cycles }\end{array}$ & Internet \\
\hline 3 & $\begin{array}{c}\text { Statements \& } \\
\text { Reports }\end{array}$ & $\begin{array}{c}\text { Computerized } \\
\text { Accounting } \\
\text { Systems }\end{array}$ & $\begin{array}{l}\text { Analysis \& } \\
\text { Design }\end{array}$ & $\begin{array}{c}\text { System Analysis } \\
\text { \& Design }\end{array}$ & $\begin{array}{c}\text { System } \\
\text { Documentation }\end{array}$ & $\begin{array}{c}\text { Transaction } \\
\text { Processing } \\
\text { Systems \& } \\
\text { Cycles }\end{array}$ \\
\hline 4 & Revenue Cycle & $\begin{array}{l}\text { Presentation \& } \\
\text { Storage of Data }\end{array}$ & $\begin{array}{c}\text { Revenue \& } \\
\text { Expense Cycles }\end{array}$ & $\begin{array}{c}\text { Technology of } \\
\text { AIS }\end{array}$ & Computer Fraud & Ethics \\
\hline 5 & Internal Control & $\begin{array}{c}\text { Systems } \\
\text { Development } \\
\text { Life Cycle }\end{array}$ & File \& Database & $\begin{array}{c}\text { Data Modeling \& } \\
\text { Database }\end{array}$ & $\begin{array}{c}\text { Database } \\
\text { Management } \\
\text { Systems }\end{array}$ & Software \\
\hline 6 & Journal Entries & & Overview & & $\begin{array}{l}\text { Database File } \\
\text { Architecture }\end{array}$ & $\begin{array}{c}\text { End User } \\
\text { Computing }\end{array}$ \\
\hline 7 & Accounts Payable & & $\begin{array}{c}\text { Evaluation \& } \\
\text { Selection }\end{array}$ & & E-commerce & $\begin{array}{c}\text { Communication } \\
\text { Topics }\end{array}$ \\
\hline 8 & $\begin{array}{c}\text { Billing \& } \\
\text { Collections }\end{array}$ & & Implementation & & Ethics & $\begin{array}{c}\text { File Organization } \\
\text { \& Access }\end{array}$ \\
\hline 9 & $\begin{array}{c}\text { Computer } \\
\text { Assisted Audit }\end{array}$ & & $\begin{array}{l}\text { Management } \\
\text { Functions }\end{array}$ & & $\begin{array}{c}\text { End User } \\
\text { Computing }\end{array}$ & Networking \\
\hline 10 & EDP Auditing & & $\begin{array}{c}\text { Database } \\
\text { Management } \\
\text { Systems }\end{array}$ & & $\begin{array}{l}\text { Electronic Data } \\
\text { Interchange }\end{array}$ & Computer Fraud \\
\hline
\end{tabular}




\section{Contributions of This Study}

This study contributes to the literature in several ways. The survey used in this study targeted the Information Systems (IS) and Artificial Intelligence / Emerging Technology (AI/ET) sections of the AAA. Therefore, the survey specifically aims at the domain of ET and the individuals who are familiar with the current issues. Accordingly, the survey responses were completed by those who have informed opinions. In this study the survey contained a list of technologies and the survey also allowed faculty to add to the list. Therefore, the survey responses emerged from the respondents rather than being predefined by the researchers. This should reduce framing bias (Judd, Smith and Kidder 1991) and allow the respondents to include a wide variety of perceptions.

The survey results were compared to the AICPA's (American Institute of Certified Public Accountants) Top Technologies. The AICPA's Top Technologies list is a prominent and well established ranking of professional interests which has never been compared to academic interests. It is important to ascertain the degree to which academics agree with the AICPA's Top Ten. This knowledge can help the accounting profession determine if a large gap exists between the two communities.

\section{RESEARCH AND SAMPLING METHODS}

In this study, Accounting Information Systems (AIS) professors were surveyed by mail in 2003. The sample was taken from members of the AAA Information Systems (IS) section and AAA Artificial Intelligence and Emerging Technology (AI/ET) section.

We only surveyed faculty with an interest in AIS and asked the faculty to classify their top five interests. In this study, the survey allowed faculty to add to the list of suggested technologies. Therefore, the responses emerged from the respondents rather than being predefined by the survey. Each survey was pre-numbered, included a cover letter explaining the purpose of the survey, and a business reply envelope which was return postage paid for US mailings. In addition to technology interests, respondents were also asked to supply demographic and other information. The survey question related to faculty interests is displayed below:

Of the following, what are your five most primary areas of interest in AIS: 1) Information Security, 2) Database Application and Integration, 3) E-commerce, 4) ERP Systems, 5) Networking, 6) System Design, 7) Decision Support and Expert Systems, 8) Computerized Transaction Processing, 9) Auditing EDP Systems, 10) Electronic Reporting, 11) Other? Please specify in the response column.

Individual faculty members were used to pretest the survey. The survey was distributed to five professors who examined and tested the survey for time, clarity, relevance and understandability. The survey was adjusted to incorporate several suggested improvements.

\section{SURVEY RESULTS AND DESCRIPTIVE STATISTICS}

Surveys were mailed to 936 accounting academics and 146 respondents completed the survey. According to Alreck and Settle (1995), response rates for mail surveys are normally five to ten percent and response rates above 30 percent are rare. The usable response rate from this survey was $15.6 \%$ and the response statistics are listed below:

- $\quad$ Population of AIS Faculty Indicating D (computer) or S (systems) Based on Hasselback (2004): 1,288

- $\quad$ Surveys Mailed: 936 (sample is $936 / 1,288=72.7 \%$ of population)

- $\quad$ Surveys Returned: 162

- $\quad$ Unusable Surveys: 16

- Usable Surveys: 146 (data set is $146 / 1,288=11.3 \%$ of population)

- Total Response Rate: $17.3 \%$ (total response rate is $162 / 936=17.3 \%$ of surveys mailed)

- Usable Response Rate: $15.6 \%$ (usable response rate is 146 / $936=15.6 \%$ of surveys mailed) 
A 15.6 percent usable response rate may raise question of non-response bias. However, the respondents represent the diversity of the population in many respects. For example, AACSB (Association to Advance Collegiate Schools of Business) accredited schools and qualified faculty were well represented.

Exhibit 3 displays university profiles where the respondents work. Exhibit 3 shows that 65.8 percent of the respondents were from AACSB accredited schools and 79.5 percent of the respondents were from AACSB accredited schools or schools that are candidates for accreditation. Faculty at AACSB accredited and AACSB candidate schools may be more desirable respondents because of their increased focus on research and publishing. The emphasis on publishing that must be demonstrated for faculty to be designated as academically and professionally qualified should make respondents from AACSB accredited schools very knowledge about the emerging technologies in their fields.

Exhibit 3: University Profiles Where Respondents Work

\begin{tabular}{|l|c|l|c|}
\hline AACSB Status & Percent & $\begin{array}{l}\text { Number of Full Time Faculty in the } \\
\text { Business Div. }\end{array}$ & Percent \\
\hline Not AACSB Accredited & 20.5 & No Response & 1.5 \\
\hline Candidate for Accreditation & 13.7 & 0 to10 & 4.1 \\
\hline AACSB Accredited & 65.8 & 11 to 20 & 6.8 \\
\hline Total & 100.0 & 21 to 30 & 10.3 \\
\hline & & 31 to 40 & 13.0 \\
\hline Type of College & Percent & 41 to 50 & 8.2 \\
\hline Private College & 30.1 & 51 to 60 & 7.5 \\
\hline Public College & 69.9 & 61 to 70 & 9.6 \\
\hline Total & 100.0 & Greater than 70 & 39.0 \\
\hline & & Total & 100.0 \\
\hline College Location & Percent & & Percent \\
\hline No Response & 1.4 & Highest Business Related Degrees & \\
\hline Canada & & Awarded & 2.0 \\
\hline South America & 1.4 & Associate & 31.0 \\
\hline Asia & .7 & Bachelor & 19.5 \\
\hline Europe & 8.2 & Master of Science & 27.1 \\
\hline Australia & 2.7 & MBA & 16.7 \\
\hline USA & 1.4 & Doctorate & 3.7 \\
\hline Total & 84.2 & Other & 100.0 \\
\hline
\end{tabular}

Approximately 84.2 percent of the respondents were from the United States. Two factors may have caused skewed results in geography. First, the original sample only included approximately 22 percent foreign professors. Secondly, due to budget constraints, return postage was not included for foreign survey participants. Therefore, anyone responding from outside the United States was required to pay postage to return the survey. The fact that the majority of the respondents were from the United States may reduce the usefulness of the results for understanding the perceptions of emerging technologies by international faculty.

Exhibit 4 displays respondent profiles. As seen in Exhibit 4, 78.8 percent of the respondents have earned a $\mathrm{Ph}$. D. or DBA, which may further contribute to the credibility of this sample. Over 41 percent of the sample held a tenured position and 63 percent of the sample was either an Assistant or Associate Professor. Slightly more than 17 percent of the faculty held the rank of Full Professor. The respondents to the survey were experienced faculty since some 65 percent had over five years of full time teaching experience. 
Exhibit 4: Respondent Profiles

\begin{tabular}{|c|c|c|c|c|}
\hline Faculty Rank & Percent & Refereed Journal Publications & Percent & Cumulative Percent \\
\hline Adjunct & 1.4 & 0 & 21.9 & 21.9 \\
\hline Lecturer or Instructor & 6.2 & 1 to 3 & 22.7 & 44.6 \\
\hline Assistant & 35.6 & 4 to 6 & 10.3 & 54.9 \\
\hline Associate & 27.4 & 7 to 9 & 6.9 & 61.8 \\
\hline Professor & 17.1 & 10 to 12 & 11.7 & 73.5 \\
\hline Distinguished & 3.4 & 13 to 15 & 3.5 & 77.0 \\
\hline Emeritus & .7 & 16 to 18 & .7 & 77.7 \\
\hline Student & 6.8 & 19 to 21 & 4.8 & 82.5 \\
\hline No Response & 1.4 & 22 to 24 & 1.4 & 83.9 \\
\hline \multirow[t]{2}{*}{ Total } & 100.0 & 25 to 27 & 3.4 & 87.3 \\
\hline & & 28 to 30 & 1.4 & 88.7 \\
\hline Tenure Status & Percent & Greater Than 30 & 6.2 & 94.9 \\
\hline Non-tenured & 55.5 & No Response & 5.1 & 100.0 \\
\hline Tenured & 41.8 & Total & 100.0 & \\
\hline No Response & 2.7 & & & \\
\hline Total & 100.0 & & & \\
\hline Highest Degree Earned & Percent & Years of Full Time Teaching & Percent & Cumulative Percent \\
\hline Associate & .7 & 0 to 5 & 31.5 & 31.5 \\
\hline Bachelor & .7 & 6 to 10 & 18.5 & 50.0 \\
\hline Master & 15.8 & 11 to 15 & 16.4 & 66.4 \\
\hline JD or LLM & 0 & 16 to 20 & 11.6 & 78.0 \\
\hline ED & .7 & 21 to 25 & 7.5 & 85.5 \\
\hline $\mathrm{PhD}$ or $\mathrm{DBA}$ & 78.8 & Greater than 25 & 11.0 & 96.5 \\
\hline No Response & 3.3 & No Response & 3.5 & 100.0 \\
\hline Total & 100.0 & Total & 100.0 & \\
\hline
\end{tabular}

The respondents to the survey indicated a total of 39 interests and the top 10 are displayed in Exhibit 5. It is no surprise that database and information security issues are on the list; however, auditing EDP systems has appeared as the top issue for the first time. E-commerce is also appearing as a more important topic in this study when it is compared with the earlier studies.

Exhibit 5: Teaching \& Research Interests of AAA Members

\begin{tabular}{|l|l|}
\hline Rank & Technology \\
\hline 1 & Auditing EDP Systems \\
\hline 2 & E-Commerce \\
\hline 3 & Database and Application Integration \\
\hline 4 & Decision Support and Expert Systems \\
\hline 5 & ERP Systems \\
\hline 6 & Information Security \\
\hline 7 & System Design \\
\hline 8 & Electronic Reporting \\
\hline 9 & Computerized Transaction Processing \\
\hline 10 & Networking \\
\hline
\end{tabular}

Exhibit 6: AICPA Top Technologies for 2004

\begin{tabular}{|l|l|}
\hline Rank & Technology \\
\hline 1 & Information Security \\
\hline 2 & Spam Technology \\
\hline 3 & Digital Optimization \\
\hline 4 & Database And Application Integration \\
\hline 5 & Wireless Technology \\
\hline 6 & Disaster Recovery \\
\hline 7 & Data Mining \\
\hline 8 & Virtual Office \\
\hline 9 & Business Exchange Technology \\
\hline 10 & Messaging Applications \\
\hline
\end{tabular}

The AICPA surveyed its members regarding their perceptions of the top ten technologies in 2003 and received 263 responses. The responses were compiled into their annual "2004 Top 10 Technologies" list displayed in Exhibit 6. 
When Exhibits 5 and 6 are compared, there is an obvious gap between the interests of practitioners and the interests of college professors. Only two items overlap, Information Security and, Database and Application Integration. Information Security is an important topic due to the recently enacted Sarbanes Oxley legislation. Section 404 of the act requires auditors to assess internal controls (IC) and attest to its adequacy and effectiveness at maintaining accurate and reliable financial data. Analyzing IC procedures requires auditors to think about systems and focus attention on the business processes that produce or degrade data quality.

\section{DISCUSSION OF RESULTS}

\section{Practitioner Versus Academic Points of View}

It is clear from the list generated by practitioners that emerging technologies are of interest. Many of the issues are the same as those that Chief Information Officers (CIOs) are grappling with. The list reflects an ever increasing awareness of the need for secure data at the same time that we need our data to be more mobile. In addition, data mining as well as database and application integration reflects the desire to get a greater return on investment as we reuse data in secondary applications. We want to be able use data more than once by creating data warehouses that ultimately support management decision making. The practitioner is very forward thinking and continually motivated by competitive forces. They focus not on the development of systems, but on how systems can be used for strategic purposes and competitive advantages.

Academics seem to be focused on system performance and system development since they are interested in design and networking issues. Historically, accounting education has been primarily focused on transactions and this bias is seen in the list generated by academics with items such as computerized transaction processing (TP). We also see an academic interest toward intelligent systems with focus on decision support and expert systems. Finally, we see that academics are interested in large comprehensive systems that include ERP (Enterprise Resource Planning) and electronic commerce applications.

One solution to resolve the gap between academics and practitioners is to have prominent conferences that encourage the bridging of practice and theory. It should be noted that there are a number of conferences in Security, as well as Database and Application Integration that are designed for practitioners and academics to discuss these issues. This may be the reason these two issues appear on both lists.

Another possible solution is to develop a research agenda that rewards collaboration between academics and practitioners. This would also help academics focus on research issues that are more relevant to the employers of their students.

\section{Rapidly Changing Practitioner Interests}

A review of Exhibit 7 reveals that the AICPA's Top Ten technologies change from year to year, reflecting the rapid advancement of technology in general. Some topics stay on the list year after year, with security issues being the most constant. Other topics may be quickly replaced by other emerging issues. Overall, there may be several factors contributing to the high turnover rate of technology issues. First, issues always appearing on the list may be critical success factors while transient issues may be a temporary fad. Secondly, the issues that appear frequently are those that are the most difficult to solve and work continues on resolving them over a longer period of time. 
Exhibit 7: Comparison of AICPA Top Technologies

\begin{tabular}{|l|c|c|c|}
\hline Rank & $\mathbf{2 0 0 2}$ & $\mathbf{2 0 0 3}$ & 2004 \\
\hline 1 & $\begin{array}{c}\text { Business and Financial Reporting } \\
\text { Applications }\end{array}$ & Information Security & Spam Technology \\
\hline 2 & $\begin{array}{c}\text { Training and Technology } \\
\text { Competency }\end{array}$ & Business Information Management & Digital Optimization \\
\hline 3 & Information Security \& Controls & Application Integration & Direless Technology \\
\hline 4 & Quality of Service & Web Services & Disaster Recovery \\
\hline 5 & Disaster Recovery & Disaster Recovery Planning & Data Mining \\
\hline 6 & Communication Technologies & Wireless Technology & Virtual Office \\
\hline 7 & Remote Connectivity Tools & Intrusion Detection & Business Exchange Technology \\
\hline 8 & Internet Applications & Remote Connectivity & Messaging Applications \\
\hline 9 & Quality IT Personnel & Customer Relationship Management & Privacy \\
\hline 10 & Messaging Applications & & \\
\hline
\end{tabular}

The rapidly changing Top 10 Technologies may also be a reflection of the US economy's shift from manufacturing to a service based economy. Service industries such as health care, accounting, finance and insurance depend on large amounts of data as well as sophisticated information technologies.

As a result of this rapidly changing list, there is frequently a "disconnect" between what practitioners want their newly hired students to know and what academics are willing and able to teach. The educational system is not designed to move quickly, whereas industry must rapidly respond to market forces in order to stay competitive. A new AIS curriculum would take at least a year from idea to actual implementation since the changes may be routed through a hierarchy of advisory boards, curriculum committees, state regulatory agencies, and various administrators. In that time, the rapidly changing interests of practitioners will demand that different technologies be taught.

Students must attend college to "learn how to learn" as part of the solution to this problem. As long as emerging technologies (ET) are included in the curriculum, students will have the opportunity to develop skills in learning new tools and techniques. When they graduate, they can apply these skills to learn the technology that is demanded by the marketplace at the moment. This is the pedagogy used in the related field of Management Information Systems (MIS). Freshman MIS students may learn to program using Java but find that by senior year another computer language is dominating industry. However, students should have the skills to learn a new language and will approach the job market knowing that they will be constantly updating their skills as life long learners.

Focus should be on the learning process when teaching students emerging technologies. Currently many technologies are taught using a style that focuses on "how-to" rather than "why". Students should become familiar with reference books and problem solving skills. Academics cannot teach all the different software packages, accounting systems, and computer languages used in the business world. The analytical thinking skills learned by using one software package can be transferred to a variety of IT applications.

Students must move beyond knowledge of the technology and into comprehension, application and analysis of the technology. This progression of learning is known as Bloom's taxonomy of educational objectives (Bloom, Engelhart, Furst, Hill and Krathwohl 1956). It requires increasing levels of sophistication as the student moves up the taxonomy and masters higher level thinking skills. These thinking skills will enable students to learn new technology during the college years and beyond. Academics must do a better job of teaching students how to learn instead of teaching them a technology that will be rapidly outdated.

\section{Process versus Static Thinking}

"Manumation" is the automation of manual transactions. Computerized transaction processing (TP) is an example of automating the same processes that have been used with manual systems. Electronic reporting uses a new medium that can do more than just generate traditional reports. Management must recognize that an opportunity is available to reengineer processes when introducing technology into an organization. 
Practitioners and academics must comprehend database processes to ensure an appropriate understanding of accounting and enterprise systems. If practitioners do not understand database processes, it can lead to costly mistakes by management. Practitioners may or may not be writing queries, but must possess the analytical skills to efficiently understand sophisticated processes. For example, when a client's substantive evidence is contained in a database, the auditor must gain access to the data warehouse to substantively test their client's work. Accordingly, the practitioner needs to be able to communicate needs to IT staff who can write more advanced queries. Hence, such communication and teamwork skills should be included in accounting programs.

In addition to databases, another technological trend that will affect the financial reporting process is markup languages. The creation of languages such as XBRL (eXtensible Business Reporting Language) will allow for the rapid communication of data between organizations, systems and networks. XBRL can allow users to increase the speed of the financial reporting process and it may lead to a continuous reporting process in the future. In the short run, XBRL will soon be used by the SEC (Securities Exchange Commission) to accept financial reports that contain data in XBRL compliant form. Since XBRL based tags can be used to identify grains of data for financial applications, new ways of understanding the financial reporting process and testing data quality will have to be developed.

With the increasing regulation of the accounting profession, data needs to be managed in such a way to provide accurate information to a variety of statutory and government agencies, such as the Securities and Exchange Commission (SEC), Internal Revenue Service (IRS) and the National Association of Insurance Commissioners (NAIC). Such data needs to be collected efficiently, stored in a common format, reported accurately and used to contribute to the information value chain. The accountant should possess the analytic skills necessary to glean the appropriate data, produce value added information, and make more informed reporting decisions.

\section{The Effect on Practitioners, Decision Making and the Accounting Profession}

The effect of the gap between practitioners and academics causes practitioners to spend resources and time training newly minted undergraduate and graduate students. For example, Price Waterhouse Coopers spends thousands of dollars training each new junior in auditing techniques. If fresh college graduates are asked to audit technologically sophisticated clients and they are not prepared for the challenge, audit risk may increase.

In addition, if new graduates in industry are trying to perform complex data management and querying without the appropriate skills, increases in the risk of material misstatements in financial information will result. Accordingly, this increases the risk of making inappropriate business decisions due to misleading information or poor decision making skills. Such mistakes reflect badly on the academic institutions the students graduate from.

According to Steve Albrecht and Robert Sack in their March 2001, CPA Journal article, "Class time devoted to information gathering and recording is pointless, because information is inexpensive and readily available. Students do not have a thorough understanding of technologies impact on business. Nor are they cognizant of how technology can be leveraged to make business decisions." Accordingly, there should be a less narrow focus on procedures and more focus on decision making. Accounting students must understand how technologies will create value and competitive advantage by blending their understanding of the strategic decision making concepts with the functionality of the technologies.

For example, complex spreadsheets are being used by many managers as decision making tools. This is posing greater audit risk since the spreadsheet cells could have programming mistakes in formulas. Freshly graduated accounting students will need to be able to understand complex spreadsheets and determine that the information processes are programmed correctly. Therefore, students must learn how to model spreadsheets for use as decision aids instead of using them as automated worksheets.

According to Dennis Beresford (FASB Chairman 1987 to 1997), "students are uncomfortable dealing with issues that require professional judgment or are otherwise ambiguous" (CPAJ January 2004). Introducing more case studies into the curriculum will allow the student to increase their critical thinking skills. It is important that the cases 
feature some ambiguous issues that develop professional judgments. Students should learn to work in teams on complex scenarios, agree on professional judgments, and communicate solutions through consulting reports and presentations. The curriculum should include opportunities to define a problem, map out a strategy, and implement a solution on time and within budget. Moreover, students should learn how to run an audit or consulting engagement at a senior or manager level.

\section{CONCLUSION AND SUGGESTIONS FOR FUTURE RESEARCH}

\section{Conclusion}

In summary, academics and practitioners are likely to continue to differ in their perceptions of what should be on a Top Ten Technologies list. Both parties have valid points of view. Knowledge of new technologies is important, but there are only a finite number of courses that a student can take in four or five years. Practitioners must recognize that academics can not gear up as quickly as industry and academics must recognize that they may need to spend more time in understanding the emerging technology needs of industry. Finally, students must learn how to learn and graduate with a curiosity that motivates them to update their skills on the latest technologies through continuing professional education.

\section{Future Research Opportunities}

The results presented in this paper could be expanded by increasing the international response rate. Accordingly, the differences in perceptions of American AIS faculty and international AIS faculty could be investigated. Another method for increasing the response rate is to survey the members of other relevant professional organizations such as the AIS Educator Association. One could argue that the responses to this study were bias by a sample selected exclusively from the AAA.

One drawback of this study is that AIS professors may give favorable scores to the technologies they are familiar with and as a result bias the rankings. Perception based rankings may be self-serving and result from predispositions instead of focusing on important emerging technologies.

In the future, the most important research may be directed at attempting to find effective and efficient ways to bridge the gap between academics and practitioners. This may involve some form of partnerships between professional and academic organizations related to facilitate the exchange of ideas and experiences. Given the great number of emerging technologies that are on the horizon, the profession may not have the resources to address all interests.

The profession would be well served by agreeing on a focus and becoming competent professionals in a subset of technology issues. In this way the accounting profession can provide a unique value added service to the business community. Before this occurs, academics and practitioners will have to agree on a long term technology strategy that will focus on producing highly trained professionals. A framework for this technology strategy could be the subject of several research projects.

\section{ACKNOWLEDGEMENTS}

We appreciate the insightful comments supplied by the anonymous reviewers of the 2005 Northeast American Accounting Association Meeting. 


\section{REFERENCES}

1. Accounting Education Change Commission, "Objectives of Education for Accounts: Position Statement Number One", Issues in Accounting Education, Fall, Vol. 5, No. 2, 1990.

2. $\quad$ Alreck, P. L. and Robert B. Settle, The Survey Research Handbook, second edition, Irwin, Chicago, IL, 1995.

3. Albrecht, W. Steve and Robert J. Sack, Accounting Education: Charting the Course through a Perilous Future, American Institute of Certified Public Accountants and the American Accounting Association, Accounting Education Series, Vol. 16, www.aicpa.org/edu/accteduc.htm, 2000.

4. Albrecht, W. Steve and Robert J. Sack, "The Perilous Future of Accounting Education”, The CPA Journal, March, 2001.

5. American Institute of Certified Public Accountants, “AICPA Top Technologies”, www.cpa2biz.com, 2004, 2003, 2002.

6. Bacon, Donald R., Kim A. Stewart and William Silver, "Lessons from the Best and Worst Student Team Experiences: How a Teacher Can Make the Difference", Journal of Management Education, July, Vol. 23, No. 5, 1999.

7. Bain, Craig E., Alan I. Blankley and Murphy Smith, "An Examination of Topical Coverage for the First Accounting Information Systems Course", Journal of Information Systems, Fall, Vol. 16, No. 2, 2002.

8. Beresford, Dennis R., "Some Thoughts on Students and Faculty", The CPA Journal, January, 2004.

9. Bland, Sandra, "A Comparison of the Opinions of Accounting Academics and Accounting Practitioners about Technology Knowledge Needed by Entry-Level Accountants", Accounting Information Systems Educators Conference Archives, www.ais-educ.com/archive.htm, 2002.

10. Bloom, B. S., M. D. Engelhart, E. J. Furst, W. H. Hill, and D. R. Krathwohl, “Taxonomy of Educational Objectives”, Handbook I: Cognitive Domain. Longman Publishers, New York, NY, 1956.

11. Brooks, Charles M. and Janice L. Ammons, "Free Riding in Group Projects and the Effects of Timing, Frequency, and Specificity of Criteria in Peer Assessments", Journal of Education for Business, May/June, Vol. 78, No. 5, 2003.

12. Bryant, Stephanie M., "A Blueprint for an AIS Consulting Course", Journal of Information Systems, Spring, Vol. 15, No. 1, 2001.

13. Calderon, Thomas G., David H. Olsen and Edward J. Conrand, "Database Coverage in the Accounting Information Systems Course", Journal of Accounting and Computers, Issue 12, 1996.

14. Callaghan, Joseph, Arline Savage and Eileen Peacock, "Rethinking AIS: An Innovative Financial Information Systems Curriculum", Accounting Information Systems Educators Conference Archives, www.ais-educ.com/archive.htm, 2002.

15. Cerullo, Michael J., "Content of the Accounting Systems Course”, Journal of Data Education, January, pp. 19-21, 1981.

16. Davis, James R. and Robert A. Leitch, “Accounting Information Systems Courses and Curricula: New Perspectives", Journal of Information Systems, Fall, pp. 153-166, 1988.

17. Doost, Roger, Gary B. Mc Combs and Mohsen Sharifi, "The State of Accounting Information Systems Education and Accounting Professional Expectations: Is There a Gap?" Accounting Information Systems Educators Conference Archives, www.ais-educ.com/archive.htm, 2002.

18. Ellen, Nicky and John West, "Classroom Management of Project Management: A Review of Approaches to Managing a Student's Information System Project Development", Journal of American Academy of Business, September, Vol. 3, 2003.

19. Foster, Benjamin, P. Julia N. Karcher and Alan S. Levitan, "Gender and Accountants' Use of Technology", The CPA Journal, February, 2003.

20. Groomer, S. Michael and Uday S. Murthy, “An Empirical Analysis of the Accounting Information Systems Course", Journal of Information Systems, Vol. 10, No. 2, Fall, pp. 103-127, 1996.

21. Heady, Cynthia D. and Ernest A. Rakow, "Course Content of Accounting Information Systems: Do Professors Agree?” Accounting Educators' Journal, Winter, pp. 140-158, 1991.

22. Judd, C. M., E. R. Smith, and L. H. Kidder, Research Methods in Social Relations, sixth edition, Holt, Rinehart and Winston, London, UK, 1991. 
23. Karim, Khondkar, Ashutosh Deshmukh and Jeffrey Romine, "XBRL in the Classroom: A Review of the Current Situation", Accounting Information Systems Educators Conference Archives, www.aiseduc.com/archive.htm, 2003.

24. Katzenbach, Jon R. and Douglas K. Smith, “The Wisdom of Teams”, Small Business Reports, July, Vol. 18, No. 7, 1993.

25. Mock, T. J., B. E. Crushing, G. B. Davis, M. A. Vasarhelyi, C. E. White and J. W. Wilkinson, "Report of the AAA Committee on Contemporary Approaches to Teaching Accounting Information Systems", Journal of Information Systems, Spring, pp. 127-156, 1987.

26. Milliron, Valerie C., "Developing AIS/ERP Professionals: Matching Market Demand and Academic Program Structure", Accounting Information Systems Educators Conference Archives, www.aiseduc.com/archive.htm, 2001.

27. Patten, Ronald and Doyle Z. Williams, "Invited Editorial: There's Trouble - Right Here in Our Accounting Programs: The Challenge to Accounting Educators", Issues in Accounting Education, Fall, Vol. 5, No. 2, 1990.

28. Ragothaman, Srinivasan and Thomas Davis, "Perceptions of Accounting Parishioners and Educators on E-business Curriculum and Web Security Issues: An Empirical Analysis", Accounting Information Systems Educators Conference Archives, www.ais-educ.com/archive.htm, 2002.

29. Robert Half International, Inc., "Next Generation Accountant: New Competencies, Converging Disciplines and Expanding Roles", www.nextgenaccountant.com, 2004.

30. Smith, L. Murphy and Craig E. Bain, "The Scope of the Accounting Information Systems Course: Based on Textbook Coverage and a Faculty Survey”, Accounting Educators' Journal, Vol. V, No. 2, pp. 1-11, 1993.

31. Uliss, Barbra and M. Virginia Parker, "Emerging AIS Issues and Their Growing Importance in the Accounting Curriculum", Accounting Information Systems Educators Conference Archives, www.aiseduc.com/archive.htm, 2001.

32. Vangermeersch, Richard, "Fifty Reasons for the Decline in the Quantity and Quality of Accounting Majors", The CPA Journal, January, www.nysscpa.org/cpajournal/2000/0100/soonJan.htm, 2000.

33. Vangermeersch, Richard, "Some Proposed Solutions for the Decline in the Quantity and Quality of Accounting Majors", The CPA Journal, January, 2001.

34. Wallace, Wanda A., "One Educator's View of How to Respond to the Challenges Faced by Higher Education in Business", Issues in Accounting Education, Fall, Vol. 5, No. 2, 1990.

35. Westbrook, Curt, "Impact of the Sarbanes-Oxley Act of 2002 on Accounting Information Systems", Accounting Information Systems Educators Conference Archives, www.ais-educ.com/archive.htm, 2003. 


\section{NOTES}

